\title{
PENGARUH LAMA PENGERINGAN TERHADAP MUTU MANISAN KERING BUAH CARICA (Carica candamarcensis)
}

\author{
Mulya Yunita ${ }^{1}$ \& Rahmawati ${ }^{2 *}$ \\ ${ }^{1,2}$ Jurusan Teknologi Pangan Universitas Sahid Jakarta \\ ‘rahmafarasara@gmail.com
}

\begin{abstract}
ABSTRAK. Carica merupakan buah khas daerah Dieng yang memiliki rasa asam, pahit dan air tinggi, sehingga buah jarang dikonsumsi segar dan cepat rusak. Salah satu upaya untuk meningkatkan kegunaan buah, dengan mengurangi rasa asam dan kandungan airnya maka dibuat menjadi manisan kering. Manisan kering merupakan makanan ringan yang awet, dibuat dengan menambahkan gula dan mengeringkannya. Penelitian bertujuan mempelajari waktu pengeringan untuk memperoleh manisan kering buah carica berkualitas baik berdasarkan uji fisik (kekerasan dan rendemen), kimia (serat kasar, kadar air, kadar abu, protein, lemak, karbohidrat by different, Aw, total padatan terlarut, total gula dan total asam) serta uji organoleptik (uji mutu hedonik untuk warna, bau, tekstur, dan rasa; serta uji rangking berdasarkan tekstur). Data dianalisa dengan uji Anova dan uji lanjut Duncan. Waktu pengeringan yang digunakan adalah 9, 9.5, 10, 10.5 dan 11 jam. Hasil menunjukkan bahwa waktu pengeringan 10 jam menghasilkan produk terbaik. Karakteristik produk ini adalah mempunyai kekerasan 5593.28gf, rendemen 26.14\%, serat kasar 1.08\%, kadar air $20.05 \%$, kadar abu $0.88 \%$, kadar protein $1.39 \%$, lemak $0.012 \%$, karbohidrat by different $77.68 \%$, aw $0.62 \%$, total padatan terlarut $39.39 \%$ total dissolve solid, total gula $45.86 \%$, total asam $0.61 \%$, berwarna kekuningan, aroma buah kuat, tekstur yang kenyal dan berasa manis.
\end{abstract}

Kata Kunci: buah carica, manisan kering, waktu pengeringan

\section{PENDAHULUAN}

Carica merupakan buah khas daerah Dieng khususnya di Kabupaten Wonosobo. Ketersediaan tanaman carica di cukup banyak (Distan Wonosobo, 2011) dan mengandung vitamin dan mineral yang cukup lengkap (Rahayu 2012), namun buah ini tidak enak dimakan segar karena rasanya asam dan pahit meskipun buah sudah matang. Selain itu carica mengandung air tinggi, sehingga cepat rusak. Selama ini buah carica hanya enak dimakan setelah dibuat manisan basah manisan dalam sirup (Hidayat, 2000).

Untuk untuk memperpanjang masa simpan buah sehingga dapat dikonsumsi kapan saja, lebih praktis, lebih ringan dan mempunyai volume lebih kecil yang dapat mempermudah pengemasan dan proses distribusi serta memberi nilai tambah terhadap buah, maka buah carica diolah menjadi manisan kering. Mutu manisan kering buah carica yang baik dipengaruhi oleh waktu pengeringan yang tepat. Berdasarkan hal tersebut maka perlu dipelajari lama pengeringan untuk mendapatkan mutu manisan kering buah carica yang baik. Mutu manisan kering buah carica ditentukan melalui uji fisik (kekerasan dan rendemen), uji kimia (kadar serat kasar, kadar air, kadar abu, protein, lemak, karbohidrat by different, aktifitas air $\left(\mathrm{a}_{\mathrm{w}}\right)$, total padatan terlarut, kadar total gula dan kadar total asam), dan uji organoleptik (uji mutu hedonik untuk warna, aroma, tekstur, rasa; serta uji rangking berdasarkan tekstur).

\section{METODE PENELITIAN \\ Bahan dan alat}

Bahan yang digunakan dalam penelitia ini adalah buah carica, gula pasir, air, $\mathrm{Ca}(\mathrm{OH})_{2}$, garam dan air. Alat yang digunak terdiri atas alat pengolahan, alat gelas, dan alat untuk 
analisa (texture analyzer, refraktometer, $\mathrm{a}_{\mathrm{w}}$-meter, labu kjeldahl, tanur, corong Buchker dan sokhlet).

\section{Proses pembuatan manisan kering buah carica}

Prose pembuatan manisan kering buah carica disajikan pada Gambar 1.

\section{Metode Penelitian}

Penelitian ini terdiri atas 1 variabel, yaitu lama pengeringan dengan 5 taraf, yaitu 9, 9.5, 10, 10.5 dan 11 jam dan 3 kali ulangan.

\section{Teknik Pengujian}

Mutu manisan kering buah carica ditentukan dengan uji kekerasan (Chen et al, 2002), rendemen (AOAC, 1995), serat kasar (SNI 01-2973-1992), kadar air (AOAC, 2006), kadar abu (AOAC, 2006), kadar lemak (AOAC, 2006), kadar protein (AOAC, 2006), kadar karbohidrat (by different) (AOAC 2006), aktifitas air $\left(A_{w}\right) \quad\left(A_{w}\right.$-meter $)$, total padatan terlarut (TPT) (Food Chemical Codex 2010), uji total gula sebagai kadar gula reduksi (SNI 3547-2-2008), uji kadar sakarosa (SNI 3547-2-2008), total asam (AOAC., 1995), dan uji organoleptik (uji mutu hedonik dan uji rangking)

\section{Teknik analisis data}

Data dianalisis dengan analisis ragam (ANAVA), dan tiga kali pengulangan menggunakan program aplikasi SPSS. ANAVA digunakan untuk melihat pengaruh setiap perlakuan, bila ada pengaruh maka dilakukan uji lanjut DMRT (Duncan Multiple Range Test). Uji DMRT dilakukan untuk melihat taraf yang menghasilkan perbedaan mutu.

\section{HASIL DAN PEMBAHASAN \\ A. Mutu Fisik}

Mutu fisik manisan kering carica ditentukan dengan uji kekerasan dan rendemen. Data hasil pengujian kekerasan dan rendemen disajikan pada Tabel 1.

\section{Kekerasan}

Kekerasan manisan kering buah carica dengan lama pengeringan 9 jam, 9.5 jam, 10 jam, 10.5 jam dan 11 jam secara berturut-turut adalah 5508.94gf ; 5590.66gf ; 5593.28gf ; 6707.95gf ; dan 7116.56gf. Data menunjukan bahwa kekerasan manisan kering buah carica cenderung meningkat dengan semakin lama waktu pengeringan. Hasil analisis ragam menunjukkan nilai signifikansi < 0.05 yang berarti lama pengeringan memengaruhi kekerasan secara nyata pada $\alpha=0.05$. Hasil uji lanjut Duncan menunjukkan bahwa waktu pengeringan memberikan pengaruh yang berbeda. Pengeringan menyebabkan menurunnya kadar air, di mana semakin rendah kadar air menghasilkan tekstur yang semakin keras. Hal ini sejalan dengan Matondang (1991) yang menyatakan bahwa semakin lama waktu pengeringan, kadar air pada bahan menurun, karena penguapan air lebih banyak dan pengerutan pada bahan. Nilai kekerasan juga dipengaruhi oleh interaksi antara serat dengan panas. Serat mampu mengikat air, selulosa dan pektin. 


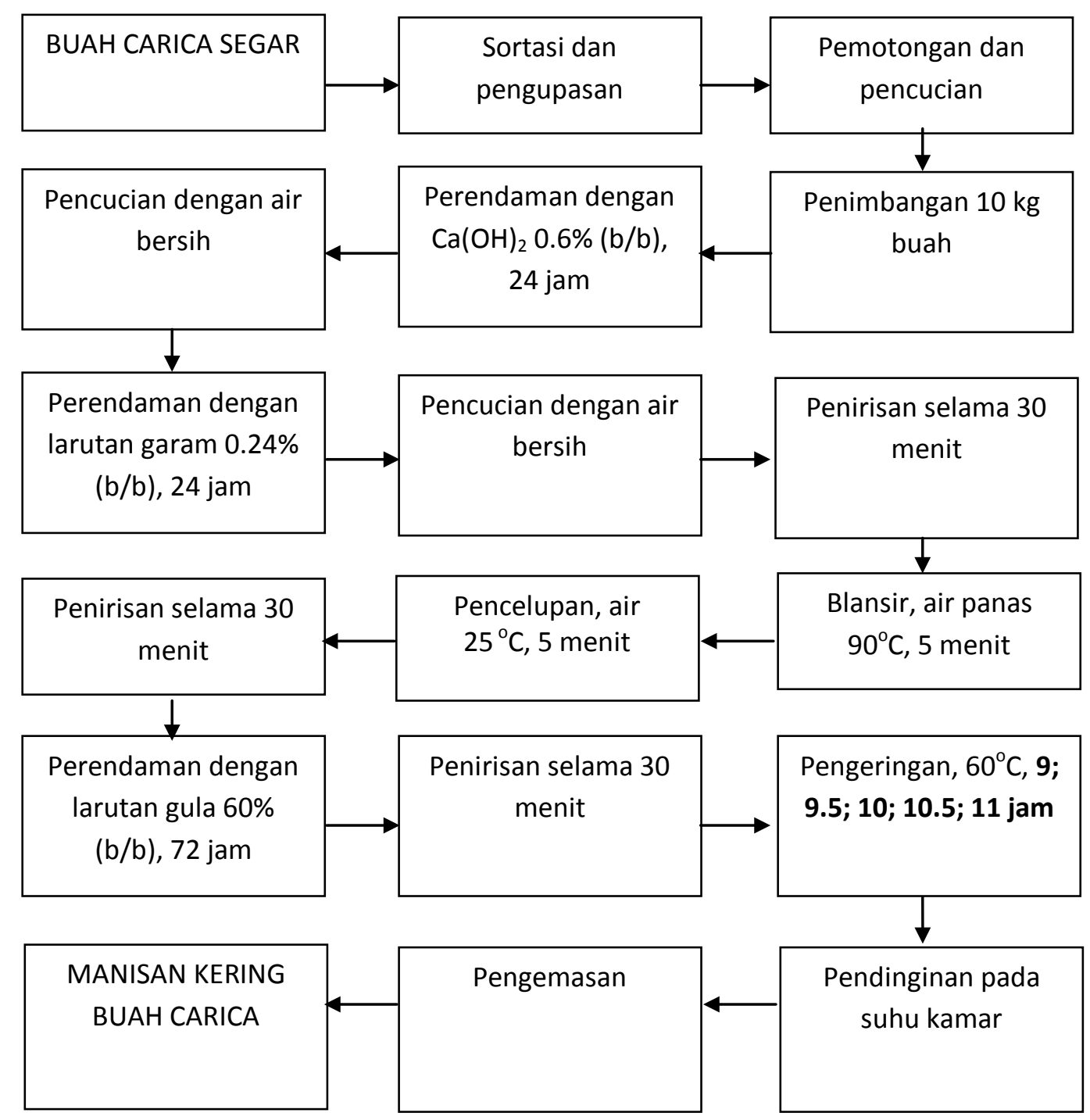

Gambar 1. Proses pembuatan manisan kering buah carica (modifikasi Fitriani, 2008)

Tabel 1. Nilai rata-rata kekerasan ( $g f$ ) rendemen manisan kering buah carica dengan lama pengeringan berbeda

\begin{tabular}{|c|c|c|c|c|c|}
\hline \multirow{2}{*}{ Jenis uji } & \multicolumn{5}{|c|}{ Lama Pengeringan } \\
\cline { 2 - 6 } & $9 \mathrm{jam}$ & $9.5 \mathrm{jam}$ & $10 \mathrm{jam}$ & $10.5 \mathrm{jam}$ & 11 jam \\
\hline Kekerasan & $5508.94 \pm 9.60^{\mathrm{a}}$ & $5590.66 \pm 7.56^{\mathrm{b}}$ & $5593.28 \pm 2.91^{\mathrm{b}}$ & $6707.95 \pm 8.47^{\mathrm{c}}$ & $7116.56 \pm 1.39^{\mathrm{d}}$ \\
\hline Rendemen & $27.72 \pm 0.63^{\mathrm{a}}$ & $27.04 \pm 0.17^{\mathrm{b}}$ & $26.14 \pm 0.10^{\mathrm{b}}$ & $25.58 \pm 0.48^{\mathrm{c}}$ & $24.34 \pm 0.26^{\mathrm{c}}$ \\
\hline
\end{tabular}

Keterangan : kode huruf di belakang angka jika sama berarti berbeda tidak nyata antara taraf perlakuan dan kode huruf berbeda berarti berbeda antara taraf perlakuan

Selain itu, pada pembuatan manisan kering buah carica dilakukan perendaman dalam larutan garam natrium klorida dan kalsium hidroksida. Hasil penelitian Vega-Galvez et al (2008) dalam Niamnuy et al (2013) mengenai efek perendaman paprika merah dalam larutan natrium klorida sebelum proses pengeringan, menyebabkan penebalan dinding sel

dengan terbentuknya kalsium pektat dan meningkatnya aktivitas enzim pectin methylesterase. Hal tersebut menyebabkan tekstur produk menjadi lebih kompak dan semakin keras seiring berkurangnya kadar air bahan. 


\section{Rendemen}

Nilai rendemen manisan kering buah carica dengan lama pengeringan 9 jam, 9.5 jam, 10 jam, 10.5 jam dan 11 jam semakin menurun dengan semakin lama pengeringan, yaitu dari $27.72 \%$ pada pengeringan 9 jam menjadi $24.34 \%$ pada lama pengeringan 11 jam. Hasil analisis ragam menunjukkan nilai signifikansi $<0.05$ yang berarti lama pengeringan memengaruhi rendemen secara nyata pada $\alpha=0.05$. Hasil uji lanjut Duncan menunjukkan bahwa waktu pengeringan memberikan pengaruh yang berbeda. Hal ini karena proses pengeringan menyebabkan produk kehilangan air akibat proses penguapan. Semakin lama waktu pengeringan maka kehilangan bobot akan semakin tinggi, yang menyebabkan rendemen semakin rendah. Kondisi ini sejalan dengan Rahmawati (2008) dalam Yuniarti et al (2013) dan Estiasih dan Ahmaadi (2011), di mana semakin besar penurunan bobot air menyebabkan penurunan kadar air semakin besar.

\section{B. Mutu Kimia}

Mutu kimia ditentukan dengan uji serat kasar, kadar air, kadar abu, kadar lemak, kadar protein, kadar karbohidrat (by different), aktifitas air $\left(A_{w}\right)$, total padatan terlarut (TPT), uji total gula sebagai kadar gula reduksi, uji kadar sakarosa, dan total asam Data hasil pengujian disajikan pada Tabel 2 .

Tabel 2. Nilai rata-rata serat kasar (\%), kadar air (\%), abu (\%), protein (\%), lemak (\%), karbohidrat (\%), Aw, dan total padatan terlarut ( ${ }^{\circ}$ Brix) manisan kering buah carica dengan lama pengeringan berbeda

\begin{tabular}{|l|c|c|c|c|c|}
\hline \multirow{2}{*}{ Jenis uji } & \multicolumn{5}{|c|}{ Lama Pengeringan } \\
\cline { 2 - 6 } & $9 \mathrm{jam}$ & $9.5 \mathrm{jam}$ & $10 \mathrm{jam}$ & $10.5 \mathrm{jam}$ & $11 \mathrm{jam}$ \\
\hline Serat kasar & $1.08 \pm 0.03$ & $1.06 \pm 0.05$ & $1.08 \pm 0.06$ & $1.05 \pm 0.06$ & $1.04 \pm 0.04$ \\
\hline Kadar air & $25.21 \pm 0.80^{\mathrm{a}}$ & $22.90 \pm 0.01^{\mathrm{b}}$ & $20.05 \pm 0.14^{\mathrm{c}}$ & $17.26 \pm 0.08^{\mathrm{d}}$ & $14.56 \pm 0.24^{\mathrm{e}}$ \\
\hline Kadar abu & $0.83 \pm 0.01^{\mathrm{a}}$ & $0.84 \pm 0.02^{\mathrm{a}}$ & $0.88 \pm 0.00^{\mathrm{b}}$ & $0.92 \pm 0.02^{\mathrm{c}}$ & $0.95 \pm 0.00^{\mathrm{d}}$ \\
\hline Protein & $1.19 \pm 0.06^{\mathrm{a}}$ & $1.27 \pm 0.06^{\mathrm{a}}$ & $1.39 \pm 0.03^{\mathrm{b}}$ & $1.40 \pm 0.06^{\mathrm{b}}$ & $1.58 \pm 0.04^{\mathrm{c}}$ \\
\hline Lemak & $0.011 \pm 0.00^{\mathrm{a}}$ & $0.012 \pm 0.00^{\mathrm{ab}}$ & $0.012 \pm 0.00^{\mathrm{ab}}$ & $0.013 \pm 0.00^{\mathrm{bc}}$ & $0.014 \pm 0.00^{\mathrm{a}}$ \\
\hline Karbohidrat & $72.76 \pm 0.85^{\mathrm{a}}$ & $74.97 \pm 0.07^{\mathrm{b}}$ & $77.68 \pm 0.16^{\mathrm{c}}$ & $80.40 \pm 0.13^{\mathrm{d}}$ & $82.90 \pm 0.26^{\mathrm{e}}$ \\
\hline Aw & $0.72 \pm 0.03^{\mathrm{a}}$ & $0.67 \pm 0.01^{\mathrm{b}}$ & $0.62 \pm 0.01^{\mathrm{c}}$ & $0.55 \pm 0.01^{\mathrm{d}}$ & $0.49 \pm 0.01^{\mathrm{e}}$ \\
\hline $\begin{array}{l}\text { Total padatan } \\
\text { terlarut }\end{array}$ & $38.55 \pm 0.29^{\mathrm{a}}$ & $38.72 \pm 0.29^{\mathrm{a}}$ & $39.39 \pm 0.00^{\mathrm{ab}}$ & $39.90 \pm 0.50^{\mathrm{bc}}$ & $40.57 \pm 0.50^{\mathrm{c}}$ \\
\hline Total gula & $43.93 \pm 0.01^{\mathrm{a}}$ & $44.97 \pm 0.24^{\mathrm{b}}$ & $45.86 \pm 0.04^{\mathrm{c}}$ & $46.39 \pm 0.01^{\mathrm{d}}$ & $46.90 \pm 0.01^{\mathrm{e}}$ \\
\hline Total asam & $0.65 \pm 0.01^{\mathrm{a}}$ & $0.62 \pm 0.01^{\mathrm{b}}$ & $0.61 \pm 0.01^{\mathrm{c}}$ & $0.59 \pm 0.01^{\mathrm{d}}$ & $0.57 \pm 0.00^{\mathrm{e}}$ \\
\hline
\end{tabular}

Keterangan : kode huruf di belakang angka jika sama berarti berbeda tidak nyata antara taraf perlakuan dan kode huruf berbeda berarti berbeda antara taraf perlakuan

\section{Serat Kasar}

Hasil pengujian kadar serat kasar manisan kering buah carica dengan lama pengeringan 9 jam, 9.5 jam, 10 jam, 10.5 jam dan 11 jam relatif sama, yaitu berturut-turut dari $1.08 \%, 1.06 \%$, $1.08 \%, 1.05 \%$ hingga $1.04 \%$ seiring dengan meningkatnya lama pengeringan. Hasil analisis ragam menunjukkan nilai signifikansi > 0.05 yang berarti lama pengeringan tidak memengaruhi kadar serat kasar secara nyata pada $\alpha=0.05$.

Serat kasar adalah bagian dari pangan yang tahan terhadap panas dan tidak dapat dihidrolisis oleh bahanbahan kimia yang digunakan. Penurunan nilai serat kasar ini disebabkan oleh dinding sel dari bahan terurai selama proses pengolahan dan lama pengeringan juga menyebabkan turunnya kadar serat kasar pada bahan (Suprapto, 2004). Hal ini karena terjadinya pemutusan ikatan 
polisakarida dan rusaknya ikatan glikosidik sehingga menghasilkan monosakarida dan disakarida. Akibatnya kadar total polisakarida (serat) yang terukur menurun dibandingkan (Mursyid, 2015).

\section{Kadar Air}

Kadar air manisan kering buah carica dengan lama pengeringan 9 jam, 9.5 jam, 10 jam, 10.5 jam dan 11 jam cenderung menurun, berturut-turut dari 25.21\% pengeringan 9 jam hingga $14.56 \%$ pada pengeringan 11 jam seiring dengan meningkatnya lama pengeringan yang digunakan. Hasil analisis ragam menunjukkan nilai signifikansi $<0.05$ yang berarti lama pengeringan memengaruhi kadar air secara nyata pada $\alpha=0.05$. Hasil uji lanjut Duncan menunjukkan bahwa waktu pengeringan memberikan pengaruh yang berbeda.

Penurunan kadar air manisan kering carica sejalan dengan Winarno (2008), di mana semakin lama waktu pengeringan menyebabkan penguapan air lebih banyak sehingga kadar air dalam bahan semakin kecil. Selain itu dengan semakin besarnya energi panas yang dibawa udara akibat semakin lamanya waktu pengeringan menyebabkan jumlah massa cairan yang diuapkan dari permukaan manisan carica semakin banyak. Kadar air manisan kering dari semua lama waktu pengeringan telah memenuhi persyaratan mutu manisan kering buahbuahan (SNI 0718-83, 2005), yaitu maksimum 25\%.

Kadar air manisan kering buah carica juga memengaruhi tekstur pada manisan, seperti semakin rendah kadar air manisan nilai kekerasan ( $g f$ ) menjadi semakin tinggi. Sulisna (2002) menyatakan bahwa pemanasan pada produk buah-buahan dapat meningkatkan kekerasan karena pemanasan dapat mengurangi ikatan pada molekul pektin dan membuatnya lebih kuat, terutama pada ikatan silang. Selain itu selama proses pengeringan telah terjadi penguraian komponen ikatan molekul air $\left(\mathrm{H}_{2} \mathrm{O}\right)$ dan meningkatkan kandungan gula, lemak, mineral dan protein sehingga meningkatkan kadar abu (Hadipernata et.al, 2006).

\section{Kadar Abu}

Kadar abu manisan kering buah carica dengan lama pengeringan berbeda (9 jam, 9.5 jam, 10 jam, 10.5 jam dan 11 jam) cenderung meningkat dari $0.83 \%$ pada lama pengeringan 9 jam hingga $0.95 \%$ pada lama pengeringan 11 jam seiring dengan meningkatnya lama pengeringan manisan kering buah carica. Hasil analisis ragam menunjukkan nilai signifikansi < 0.05 yang berarti lama pengeringan memengaruhi kadar abu secara nyata pada $\alpha=0.05$. Hasil uji lanjut Duncan menunjukkan bahwa waktu pengeringan memberikan pengaruh yang berbeda.

Meningkatnya persentase kadar abu manisan kering buah carica dengan semakin lamanya waktu pengeringan berkaitan dengan menurunnya kadar air. Semakin rendah kadar air manisan kering buah carica maka persentase kadar mineral semakin tinggi, sehingga kadar abu juga semakin tinggi (Aisyah, 2005). Nilai rata-rata kadar abu manisan kering buah carica yaitu antara $0.83 \%$ $0.95 \%$, masih memenuhi standar yang diizinkan SII 0272.90, yaitu maksimal $1.0 \%$.

\section{Protein}

Hasil pengujian kadar protein manisan kering buah carica dengan lama pengeringan yang berbeda (9 jam, 9.5 jam, 10 jam, 10.5 jam dan 11 jam) cenderung meningkat dari $1.19 \%$ pada lama pengeringan 9 jam hingga $1.58 \%$ pada lama pengeringan 11 jam. Hasil analisis ragam menunjukkan nilai signifikansi $<0.05$ yang berarti lama pengeringan memengaruhi kadar abu secara nyata pada $\alpha=0.05$. Hasil uji lanjut Duncan menunjukkan bahwa waktu pengeringan memberikan pengaruh yang berbeda.

Peningkatan kadar protein
dengan semakin lama waktu 
pengeringan disebabkan karena selama proses pengeringan telah terjadi penguraian komponen ikatan molekul air $\left(\mathrm{H}_{2} \mathrm{O}\right)$, hal tersebut menyebabkan penurunan kadar air, sehingga meningkatkan komponen lain seperti kandungan protein. Molekul air membentuk hidrat dengan molekulmolekul lain yang mengandung atomatom $\mathrm{O}$ dan $\mathrm{N}$ seperti protein (Hadipernata, 2006). Peningkatan kadar protein juga memengaruhi nilai total padatan terlarut di mana Olsen (1995) menyatakan bahwa salah satu komponen padatan terlarut yang dominan yaitu protein di samping gula, pigmen, asam organik dan vitamin. Peningkatan kadar protein memengaruhi mutu warna pada manisan kering buah carica karena karena dapat menyebabkan reaksi Maillard, yaitu reaksi antara karbohidrat, khususnya gula pereduksi dengan gugus amina primer. Hasil reaksi tersebut menghasilkan produk berwarna coklat atau disebut juga sebagai reaksi browning (Winarno, 2008).

\section{Lemak}

Kadar lemak manisan kering buah carica dengan lama pengeringan 9 jam, 9.5 jam, 10 jam, 10.5 jam dan 11 jam cenderung meningkat dari $0.011 \%$ pada lama pengeringan 9 jam hingga $0.014 \%$ pada lama pengeringan 11 jam seiring dengan meningkatnya lama waktu pengeringan. Hasil analisis ragam menunjukkan nilai signifikansi < 0.05 yang berarti lama pengeringan memengaruhi kadar lemak secara nyata pada $\alpha=0.05$. Hasil uji lanjut Duncan menunjukkan bahwa waktu pengeringan memberikan pengaruh yang berbeda.

Meningkatnya kadar lemak berkaitan dengan semakin tingginya molekul air yang teruapkan pada saat pengeringan (Hadipernata, 2006). Hal ini terjadi karena dengan semakin rendahnya kadar air manisan kering buah carica maka kadar persentase komponen lain semakin tinggi, sehingga kadar lemak yang diperoleh juga semakin tinggi (Aisyah, 2005).

\section{Karbohidrat}

Hasil pengujian kadar karbohidrat pada manisan kering buah carica dengan lama pengeringan yang berbeda (9 jam, 9.5 jam, 10 jam, 10.5 jam dan 11 jam) cenderung meningkat dari $72.76 \%$ pada lama pengeringan 9 jam hingga $82.90 \%$ pada lama pengeringan 11 jam seiring dengan meningkatnya lama waktu pengeringan. Hasil analisis ragam menunjukkan nilai signifikansi < 0.05 yang berarti lama pengeringan memengaruhi kadar lemak secara nyata pada $\alpha=0.05$. Hasil uji lanjut Duncan menunjukkan bahwa waktu pengeringan memberikan pengaruh yang berbeda.

Adanya peningkatan kadar karbohidrat (\%) dengan semakin lama waktu pengeringan disebabkan karena selama proses pengeringan telah terjadi penguraian komponen ikatan molekul air $\left(\mathrm{H}_{2} \mathrm{O}\right)$ yang menyebabkan peningkatan kandungan karbohidrat karena molekul air membentuk hidrat dengan molekul-molekul lain yang mengandung atom-atom $\mathrm{O}$ dan $\mathrm{N}$ seperti karbohidrat (Hadipernata, 2006). Selain itu, peningkatan kadar karbohidrat juga memengaruhi meningkatnya total padatan terlarut di mana semakin lama pemanasan maka gula sebagai komponen karbohidrat semakin larut sehingga total padatan terlarut meningkat (Buckle, dkk. 2009). Adanya karbohidrat dapat meningkatkan cita rasa manisan kering buah carica, yaitu rasa manis karena adanya sukrosa, tekstur yang renyah karena adanya pati, dan warna coklat keemasan yang bagus karena rekaksi Maillard antara gula dan asam amino pada saat dipanaskan

\section{Aktivitas Air}

Nilai aktivitas air $\left(A_{w}\right)$ manisan kering buah carica dengan lama pengeringan berbeda (9 jam, 9.5 jam, 10 jam, 10.5 jam dan 11 jam) cenderung menurun dari 0.72 pada lama pengeringan 9 jam hingga 0.49 pada lama pengeringan 11 jam seiring dengan meningkatnya lama 
pengeringan yang digunakan. Hasil analisis ragam menunjukkan nilai signifikansi < 0.05 yang berarti lama pengeringan memengaruhi nilai Aw secara nyata pada $\alpha=0.05$. Hasil uji lanjut Duncan menunjukkan bahwa waktu pengeringan memberikan pengaruh yang berbeda.

Menurut Muchtadi dan Ayustaningwarno (2010), bahan pangan yang mempunyai $A_{w}=0.70$ sudah dianggap cukup baik dan tahan selama penyimpanan karena bakteri, kapang, dan khamir dapat hidup pada Aw lebih besar dari 0.75 . Nilai aktivitas air manisan kering buah carica berkisar antara $0.49-0.72$. Berdasarkan grafik labuza, kerusakn yang mungkin terjadi pada manisan kering buah carica ini berada pada kisaran $a_{w} 0.30-0.80$, yaitu adanya pertumbuhan mikroba khususnya khamir osmofilik $\left(A_{w}=0.67\right)$ dan reaksi-reaksi kimia seperti browning, hidrolisis, atau oksidasi lemak (Winarno, 2008). Nilai $a_{w}$ juga dipengaruhi oleh konsentrasi gula pada produk yang diawetkan dengan cara pengeringan karena gula merupakan salah satu bahan pengawet anti mikroba alami yang dapat mengganggu lingkungan hidup mikroba, dengan pengeringan hal tersebut juga memengaruhi penurunan kadar air bahan $\left(A_{w}\right)$ sehingga meminimalkan mikroba beraktivitas (Muchtadi dan Ayustaningwarno, 2010).

\section{Total Padatan Terlarut (TPT)}

Kadar TPT manisan kering buah carica dengan lama pengeringan 9 jam, 9.5 jam, 10 jam, 10.5 jam dan 11 jam cenderung meningkat dengan nilai berkisar $38.55{ }^{\circ}$ Brix sampai dengan $40.57{ }^{\circ}$ Brix. Hasil analisis ragam menunjukkan nilai signifikansi $<0.05$ yang berarti lama pengeringan memengaruhi nilai Aw secara nyata pada $\alpha=0.05$. Hasil uji lanjut Duncan menunjukkan bahwa waktu pengeringan memberikan pengaruh yang berbeda.

Meningkatnya nilai TPT dengan semakin lama waktu pengeringan berkaitan dengan menurunnya kadar air produk. Semakin lama pengeringan, semakin banyak air teruapkan sehingga total padatan semakin tinggi. Total padatan terlarut pada buah didominasi oleh kandungan gula dan asam (Soedibyo, 2005) serta semakin lama pemanasan maka gula semakin larut dalam sari sehingga total padatan terlarut meningkat (Buckle, dkk. 2009). Kelarutan gula dalam air cukup besar dan gula merupakan fraksi padat sehingga semakin banyak gula maka padatan yang dihasilkan juga tinggi. Olsen (1995) menyatakan bahwa gula merupakan komponen padatan terlarut yang dominan di samping pigmen, asam organik, vitamin dan protein. Oleh karena itu peningkatan konsentrasi gula akan diikuti dengan peningkatan nilai total padatan terlarut. Selain itu, konsentrasi gula juga memengaruhi pertumbuhan mikroba karena gula bersifat anti mikroba alami yang dapat mengganggu lingkungan hidup mikroba. Selain itu pengeringan menyebabkan penurunan kadar air bahan dan aktivitasnya $\left(a_{w}\right)$ sehingga tidak memungkinkan mikroba aktif (Muchtadi dan Ayustaningwarno, 2010).

\section{Total Gula}

Hasil pengujian kadar total gula manisan kering buah carica dengan lama pengeringan berbeda (9 jam, 9.5 jam, 10 jam, 10.5 jam dan 11 jam) cenderung meningkat dari $43.93 \%$ pada lama pengeringan 9 jam hingga $46.90 \%$ pada lama pengeringan 11 jam seiring dengan meningkatnya lama waktu pengeringan. Hasil analisis ragam menunjukkan nilai signifikansi < 0.05 yang berarti lama pengeringan memengaruhi nilai Aw secara nyata pada $\alpha=0.05$. Hasil uji lanjut Duncan menunjukkan bahwa waktu pengeringan memberikan pengaruh yang berbeda.

Adanya peningkatan nilai total gula (\%) dengan semakin lama waktu pengeringan karena nilai total padatan terlarut meningkat seiring dengan semakin lamanya waktu pengeringan.Total padatan terlarut pada buah didominasi oleh kandungan gula dan asam (Soedibyo, 2005) serta 
semakin lama pemanasan maka gula semakin larut dalam sari sehingga total padatan terlarut meningkat (Buckle, dkk. 2009). Konsentrasi gula berpengaruh terhadap nilai total gula yang dihasilkan. Semakin tinggi konsentrasi gula akan meningkatkan total gula, karena larutan gula yang ada terdiri dari sukrosa dan beberapa komponen non sukrosa, sehingga dengan meningkatnya konsentrasi gula nilai total gula juga semakin tinggi (Luthony, 1990).

Peningkatan konsentrasi gula akan mengakibatkan warna manisan kering buah carica menjadi coklat. Winarno (2008) menyatakan bahwa reaksi pencoklatan bahan makanan yang mengandung karbohidrat dapat dipercepat oleh pengaruh pemanasan sehingga komponen gula pereduksi akan membentuk senyawa berwarna coklat. Selain itu, konsentrasi gula juga memengaruhi pertumbuhan mikroba karena gula dapat berperan sebagai pengawet karena bersifat antimikroba dengan mengganggu lingkungan hidup mikroba. Selain itu pengeringan menyebabkan penurunan kadar air bahan sehingga aktivitas air ikut menurun. Kedua hal di atas dapat menghambat mikroba untuk beraktivitas (Muchtadi dan Ayustaningwarno, 2010). Secara umum kadar total gula manisan kering carica untuk semua perlakuan telah memenuhi persyaratan mutu manisan kering buah-buahan (SNI 0718-83, 2005), yaitu minimum $40 \%$.

\section{Total Asam}

Total asam manisan kering buah carica dengan lama pengeringan berbeda (9 jam, 9.5 jam, 10 jam, 10.5 jam dan 11 jam) cenderung menurun dari $0.65 \%$ pada lama pengeringan 9 jam menjadi $0.57 \%$ pada lama pengeringan 11 jam seiring dengan meningkatnya lama waktu pengeringan. Hasil analisis ragam menunjukkan nilai signifikansi < 0.05 yang berarti lama pengeringan memengaruhi nilai Aw secara nyata pada $\alpha=0.05$. Hasil uji lanjut Duncan menunjukkan bahwa waktu pengeringan memberikan pengaruh yang berbeda.

Penurunan total asam disebabkan oleh sifat asam secara umum mudah menguap pada saat dipanaskan. Dengan semakin lama pemanasan menyebabkan resistensi asam pada buah berkurang (Budiyati dan Kristinah, 2004). Semakin lama pemanasan, maka asam-asam organik yang terdapat pada manisan kering buah carica seperti asam askorbat mengalami kerusakan, sehingga kadar total asam produk menjadi menurun. Kerusakan asam dapat dipercepat oleh adanya kontak panas yang lama, sinar, alkali, enzim, oksidator, serta katalis tembaga dan besi (Winarno, 2008).

\section{Mutu Organoleptik}

Mutu organoleptik yang diuji meliputi uji mutu hedonic untuk warna, aroma, tekstur, dan rasa, serta uji rangking untuk mengetahui produk terbaik manisan kering buah carica. Histogram hasil uji warna, aroma, tekstur dan rasa disajikan pada Gambar 1.

\section{Mutu Hedonik \\ a. Warna \\ Nilai rata-rata mutu hedonik} warna manisan kering buah carica dengan lama pengeringan berbeda (9 jam, 9.5 jam, 10 jam, 10.5 jam dan 11 jam), berkisar antara skor 3.9 sampai skor 2.6 dengan deskripsi warna kuning hingga kuning kecoklatan. Pada Gambar 1 terlihat bahwa lama pengeringan menurunkan nilai warna pada manisan kering buah carica. Hasil analisis ragam menunjukkan nilai signifikansi $<0.05$ yang berarti lama pengeringan memengaruhi warna secara nyata pada $\alpha=0.05$. Hasil uji lanjut Duncan menunjukkan bahwa lama pengeringan memberikan pengaruh yang berbeda.

Semakin lama waktu pengeringan mengakibatkan warna manisan kering buah carica menjadi coklat. Reaksi pencoklatan umumnya dibagi menjadi dua golongan, yaitu reaksi pencoklatan enzimatik dan reaksi pencoklatan non enzimatik. 
Reaksi pencoklatan non enzimatik dibagi lagi menjadi tiga macam reaksi, yaitu karamelisasi, reaksi maillard dan pencoklatan akibat pengaruh vitamin C. Winarno (2008) menyatakan bahwa reaksi pencoklatan bahan makanan yang mengandung karbohidrat dapat dipercepat oleh pengaruh pemanasan sehingga komponen gula pereduksi akan membentuk senyawa berwarna coklat. Hal ini disebabkan karena semakin lama waktu pengeringan memungkinkan terjadinya reaksi Maillard lebih besar sehingga menyebabkan manisan kering buah carica berwarna kuning kecoklatan. Pendapat ini didukung oleh Yusmarini dan Pato (2004), pengeringan dengan menggunakan suhu yang tinggi dan waktu yang lama menyebabkan kerusakan pada karbohidrat yaitu terjadinya reaksi browning non enzimatik (reaksi Maillard) dan karamelisasi. Reaksi Maillard terjadi karena adanya reaksi antara gugus amino protein dengan gugus karboksil gula pereduksi yang menghasilkan bahan berwarna coklat, sedangkan karamelisasi terjadi karena adanya reaksi antara gula dan panas.

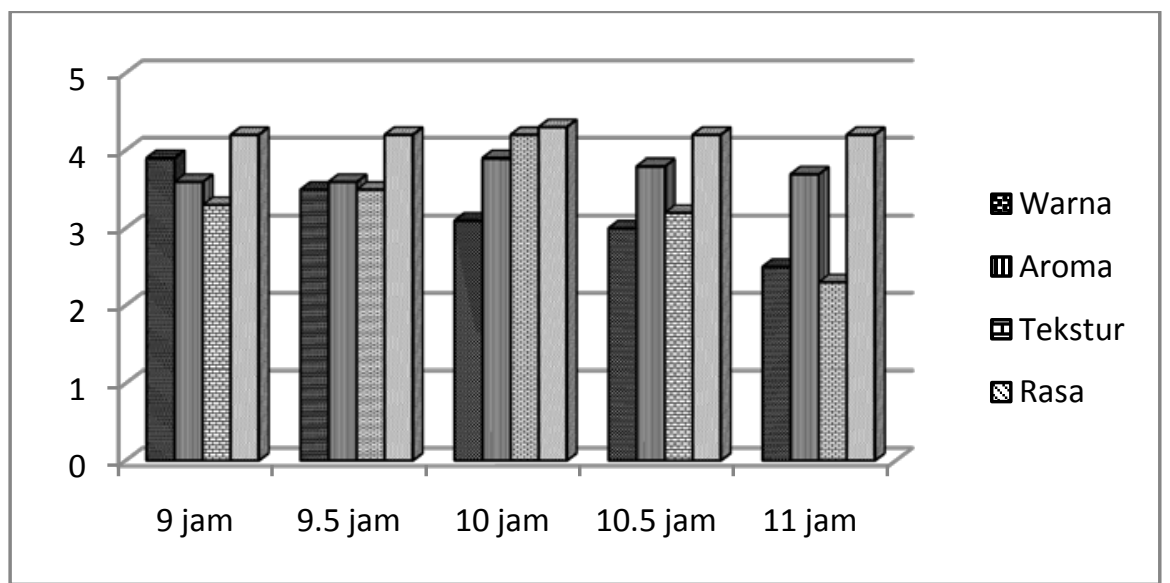

Gambar 1. Histogram uji hedonic (skor) manisan kering buah carica dengan lama pengeringan berbeda

Keterangan skor :

Warna : (1) coklat; (2) kuning-coklat; (3) kuning-oranye; (4) kuning; (5) kuning pucat;

Aroma : (1) buah sangat lemah; (2) buah lemah; (3) buah sedang; (4) buah kuat; (5)

buah sangat kuat;

Tekstur : (1) keras; (2) agak keras; (3) agak kenyal; (4) kenyal; (5) sangat kenyal;

Rasa : (1) manis sangat lemah; (2) manis lemah; (3) manis sedang; (4) manis; (5) sangat manis

b. Aroma

Hasil pengujian menunjukkan nilai rata-rata skor mutu hedonik aroma manisan kering buah carica dengan lama pengeringan 9 jam, 9.5 jam, 10 jam, 10.5 jam dan 11 jam, cenderung meningkat, secara berturut-turut skor 3.6, 3.6, 3.9, 3.8, 3.7 dengan deskripsi aroma buah sedang sampai aroma buah kuat. Pada Gambar 1 terlihat bahwa lama pengeringan menurunkan nilai aroma pada manisan kering buah carica. Hasil analisis ragam menunjukkan nilai signifikansi > 0.05 yang berarti lama pengeringan tidak memengaruhi warna secara nyata pada $\alpha=0.05$. Senyawa aromatik bersifat mudah menguap. Semakin lama pengeringan, semakin banyak senyawa yang teruapkan, namun indera manusia tidak sesensitif alat, sehingga panelis tidak dapat mendeteksi perubahan aroma secara nyata.

c. Tekstur

Mutu hedonik tekstur manisan kering buah carica dengan lama pegeringan yang berbeda cenderung fluktuatif. Nilai tertinggi skor 4.2 pada lama pengeringan 10 jam dan nilai terendah skor 2.3 pada lama pengeringan 11 jam dengan deskripsi 
tekstur kenyal hingga agak keras. Pada Gambar 1 terlihat bahwa lama pengeringan menurunkan nilai tekstur pada manisan kering buah carica. Hasil analisis ragam menunjukkan nilai signifikansi < 0.05 yang berarti lama pengeringan memengaruhi tekstur secara nyata pada $\alpha=0.05$.

Tekstur manisan kering buah carica dipengaruhi oleh lama pengeringan. Semakin lama waktu pengeringan tekstur yang dihasilkan semakin keras. Menurut Winarno (2008) lama waktu pengeringan menyebabkan penguapan air lebih banyak sehingga kadar air dalam bahan semakin kecil. Menurut Matondang (1991) pengurangan molekul air pada proses pemanasan menyebabkan pengerutan bahan dan peningkatan konsentrasi pektin, selulosa, dan bahan lain penyusun dinding sel. Di samping itu pembentukan gel dari pektin juga dipengaruhi oleh persentase gula, dengan demikian semakin besar konsentrasi pektin dan persentase gula maka semakin keras tekstur yang terbentuk. Vega-Galvez et al (2008) dalam Niamnuy et al (2013) menyatakan bahwa perendaman paprika merah dalam larutan garam natrium klorida dan kalsium klorida sebelum proses pengeringan menyebabkan penebalan dinding sel karena terbentuknya kalsium pektat melalui proses pemanasan dan meningkatkan aktivitas dari pectinmethylesterase. Hal tersebut menyebabkan tekstur produk menjadi lebih kompak dan semakin keras seiring berkurangnya kadar air bahan. Diduga hal yang sama terjadi pada tekstur manisan kering buah carica.

\section{d. Rasa}

Hasil pengujian menunjukkan nilai rata-rata mutu hedonik rasa manisan kering buah carica dengan lama pengeringan yang berbeda berkisar antara skor 4.2 sampai 4.3 dengan deskripsi rasa manis. Gambar 1 menunjukkan penurunan rasa manisan kering buah carica. Namun pada lama pengeringan 10 jam menghasilkan penilaian tertinggi terhadap rasa manisan kering buah carica. Tingginya penilaian panelis terhadap rasa manisan kering buah carica diduga karena pada perlakuan tersebut manisan kering buah carica memiliki rasa yang lebih enak yaitu rasa manis dan lebih segar karena memiliki kandungan air yang tidak terlalu tinggi sehingga teksturnya kenyal dan tidak terlalu keras.

Penilaian terhadap mutu hedonik rasa meningkat dari 4.2 pada lama pengeringan 9 jam sampai 4.3 pada lama pengeringan 10 jam. Menurut Pratiwi (2009), semakin lama waktu pemanasan maka rasa semakin meningkat karena sukrosa mampu membentuk citarasa yang baik karena kemampuannya menyeimbangkan rasa asam, pahit, atau asin melalui pembentukan karamelisasi. Namun nilai mutu hedonik menurun pada lama pengeringan 10.5 jam sampai 11 jam. Hal ini terjadi karena rasa dipengaruhi oleh beberapa faktor yaitu senyawa kimia, suhu, konsentrasi dan interaksi dengan komponen rasa yang lain (Winarno, 2008). Turunnya penilaian panelis terhadap rasa manisan kering buah carica juga diduga karena pada perlakuan tersebut manisan kering buah carica memiliki kandungan kadar air yang terlalu rendah sehingga teksturnya lebih keras.

Waktu pengeringan yang lama menyebabkan terjadinya inverse sukrosa menjadi glukosa dan fruktosa sehingga rasa manis pada manisan kering buah carica menjadi berkurang. $\mathrm{Hal}$ ini didukung oleh Achyadi dan Hidayanti (2004) yang menyatakan bahwa pengeringan menyebabkan larutan sukrosa akan mengalami inverse atau pemecahan sukrosa menjadi glukosa dan fruktosa akibat pengaruh panas yang akan meningkatkan kelarutan gula.

2. Uji Rangking

Uji rangking dilakukan berdasarkan tingkat kekenyalan manisan kering buah carica. Rangking pertama diperoleh pada manisan yang paling kenyal menurut panelis. Hasil menunjukkan rangking pertama menurut panelis adalah manisan yang 
dikeringkan selama 10 jam. Diikuti rangking kedua pada pengeringan 9.5 jam, diikuti pengeringan 9 jam, 10,5 jam dam 11 jam. Foto produk manisan kering buah carica disajikan pada Gambar 2.

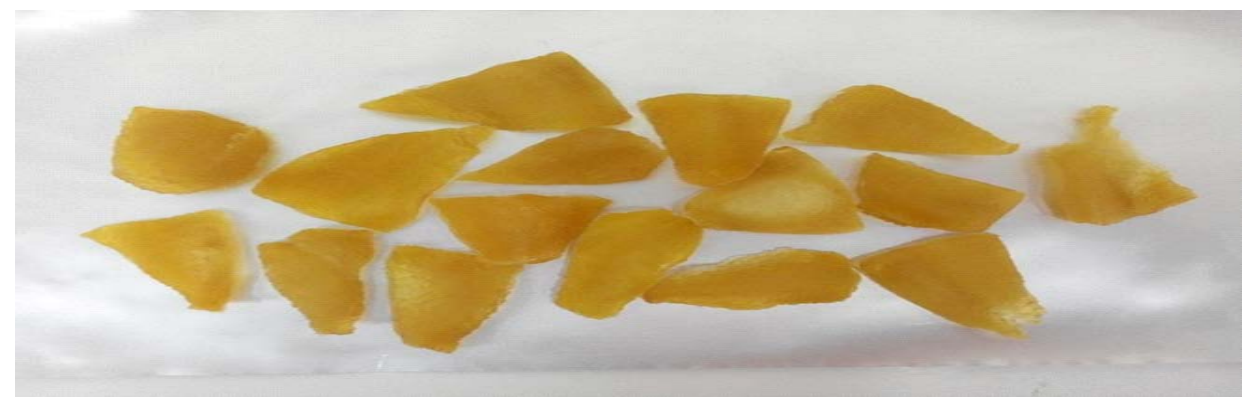

Gambar 2. Manisan kring buah carica dengan lama pengeringan 10 jam

\section{Kesimpulan dan Saran}

\section{A. Kesimpulan}

Berdasarkan uraian di atas, dapat disimpulkan bahwa lama pengeringan memengaruhi semua parameter mutu fisik yaitu kekerasan dan rendemen secara nyata pada $\alpha=0.05$. Lama pengeringan tidak memengaruhi kadar serat kasar, namun memengaruhi parameter kimia lainnya, yaitu kadar air, abu, protein, lemak, karbohidrat, Aw, TPT, total gula dan total asam secara nyata pada $\alpha=0.05$. Pada uji mutu hedonik, lama pengeringan memengaruhi warna dan tekstur manisan kering buah carica secara nyata pada $\alpha=$ 0.05, dan tidak memengaruhi aroma dan rasa.

Manisan kering buah carica yang paling disukai panelis berdasarkan uji rangking yaitu manisan kering buah carica dengan lama pengeringan 10 jam. Karakteristik mutu manisan ini adalah: memiliki kekerasan $5593.28 \mathrm{gf}$, rendemen $26.14 \%$, serat kasar $1.08 \%$, kadar air $20.05 \%$, kadar abu $0.88 \%$, protein $1.39 \%$, lemak $0.012 \%$, karbohidrat (by different) $77.68 \%$, aktivitas air $\left(\mathrm{a}_{\mathrm{w}}\right) 0.62 \%$, total padatan terlarut $39.39 \%$, nilai total gula $45,86 \%$ dan total asam $0,61 \%$ serta berwarna kuning oranye (skor 3.1), beraroma buah kuat (skor 3,9), bertekstur kenyal (skor 4,2), dan berasa manis (skor $4,2)$.

\section{B. Saran}

Disarankan untuk melakukan penelitian lanjutan untuk mengetahui umur simpan manisan kering buah carica dan pemilihan kemasan yang tepat untuk menunjang mutu manisan kering buah carica.

\section{DAFTAR PUSTAKA}

Achyadi, N.S. dan Hidayanti A. 2004. Pengaruh konsentrasi bahan pengisi dan konsentrasi sukrosa terhadap karakteristik fruit leather cempedak champedhen Lour.) (Artocarpus http://www.unpas.ac.id. Diakses pada 02 Juli 2015.

Aisyah, Y. 2005. Asam Sunti Hitam atau Putih. http://www.nad.go.id. Diakses pada 02 Agustus 2015.

Association of Official Analytical Chemist. 1995. Official Method of Analysis of The Association of Analytical Chemist. Washington DC: AOAC Inc.

Association of Official Analytical Chemist. 2006. Official Method of Analysis of The Association of Analytical Chemist. Washington DC: AOAC Inc.

Badan Standarisasi Nasional 2005. SNI 0718-83, 2005 : Syarat mutu manisan kering buah-buahan. Jakarta: Badan Standar Nasional BSN.

Buckle, K.A., R.A. Edward, G.H. Fleet dan M. Wooton, 2009. Ilmu Pangan. Diterjemahkan oleh Hari Purnomo dan Adiono. UI-Press, Jakarta.

Budiyati, C.S dan Kristinah H. 2004. Pengaruh Suhu Terhadap Kadar Vitamin C pada Pembuatan Tepung Tomat. Prosiding 
Departemen Perindustrian. SII 0272.90. Manisan Kering Buah-Buahan. Departemen Perindustrian: Jakarta

[Distan] Dinas Pertanian Subdin Hortikultura Kabupaten Wonosobo. 2011. Jumlah Tanaman Carica di Dataran Tinggi Dieng Kabupaten Wonosobo. Wonosobo: Distan Kabupaten Wonosobo.

Estiasih, T dan Kgs, Ahmaadi. 2011. Teknologi Pengolahan Pangan. Jakarta: Bumi Aksara 274 hlm; 23 $\mathrm{cm}$.

Fitriani, S. 2008. Pengaruh Suhu dan Lama Pengeringan Terhadap Beberapa Mutu Manisan Belimbing Wuluh (Averrhoa bilimbi L.) Kering. Jurnal SAGU, Vol. 7 (1) : 32-37.

Hadipernata, M. R. Rachmat dan Widaningrum. 2006. Pengaruh suhu pengeringan pada teknologi Far Infrared (FIR) terhadap mutu jamur merang kering (Volvariella volvociae). Buletin Teknologi Pascapanen Pertanian Volume 2 (2): 62-69.

Hidayat. 2000. Potensi dan Prospek Pepaya Gunung (Carica pubescens Lanne \& K. Koch) dari Sikunang, Pegunungan Dieng, Wonosobo. UPT Balai Pengembangan Kebun Raya LIPI Bogor. Bogor

Luthony, TL. 1990. Tanaman Sumber Pemanis. Penebar Swadaya. Jakarta

Matondang, S. 1991. Pengeringan Biji-Biji Hasil Pertanian. FP-USU. Medan.

Muchtadi, T.R. dan Ayustaningwarno, F. 2010. Teknologi Proses Pengolahan Pangan. Jakarta: Alfabeta.

Mursyid, M. 2015. Penurunan Kadar Serat Pangan, Pengaruh Panas dan Reaksi Maillard. http://mursyid1987.blogspot.co.id/2 014/01/penurunan-kadar-seratpangan-pengaruh.html. Diakses 7 Oktober 2015.

Niamnuy, C., S. Devahastin., dan S. Soponronnarit. 2013. Some recent advances in microstructural modification and monitoring of foods during drying: A review. Elsevier Ltd.

Olsen, H. S. 1995. Enzymatic Production of Glucose Syrups. Blackie Academic and Professional. London

Pratiwi, 2009. Formulasi, Uji Kecukupan Panas, Dan Pendugaan Umur Simpan Minuman Sari Wornas (Wortel-Nanas). http://www.repository.ipb.ac.id.

Rahayu, E.S. 2012. Kadar Vitamin Dan Mineral Dalam Buah Segar Dan Manisan Basah Karika Dieng (Carica pubescens Lenne\&K.Koch). Semarang: Biosaintifika Universitas Negeri Semarang.

Rahmawati, I. 2008. Penentuan Lama Pengeringan pada Pembuatan Serbuk Biji Alpukat (Persea Americana mill). Skripsi. Fakultas Teknologi Pertanian. Universitas Brawiajaya. Malang

Soedibyo, 2005. Karakterisasi Morfologi Lima Populasi Nenas (Ananas comosus). http://www.repository.ipb.ac.id., (10 Oktober 2012).

Sulisna, R. 2002. Pembuatan Manisan Kering Labu Mie (Cucurbita pepo L.) Kajian Konsentrasi Larutan Kapur dan Lama pengeringan Terhadap Sifat Fisik, Kimia dan Organoleptik. Skripsi. Jurusan THP, Fakultas Teknologi Pertanian Universitas Brawijaya. Malang.

Suprapto. 2004. Pengaruh Lama Blanching Terhadap Kualitas Stik Ubijalar (Ipoema Batatas L.) Dari Tiga Varietas. Balai Penelitian Tanaman Kacang-kacangan dan Umbiumbian. Malang.

Winarno, F.G. 2008. Kimia Pangan dan Gizi. Jakarta: Gramedia

Yusmarini dan Pato. 2004. Teknologi Pengolahan Hasil Tanaman Pangan. Jakarta: Gramedia Pustaka Utama. 